\title{
Comparison of the radical scavenging and a-glucosidase inhibitory activities of fingerroot extracts based on different extraction methods
}

\author{
Gyeong Han Jeong, Yun Hee Jeong, Tae Hoon Kim* \\ Department of Food Science and Biotechnology, Daegu University, Gyeongsan 38453, Korea
}

\section{추출방법에 따른 핑거루트 추출물의 라디칼 소거 및 $\alpha$-glucosidase 저해 활성 비교}

\author{
정경한 - 정윤희 · 김태훈* \\ 대구대학교 식품공학과
}

\begin{abstract}
The roots of Boesenbergia rotunda are prominent ingredients in the cuisine of several Asian countries, including Thailand, Malaysia, Indonesia, India, and China. Recently, fingerroot (Boesenbergia rotunda) was successfully cultivated in South Korea. In this study, the radical scavenging and $\alpha$-glucosidase inhibitory activities of Korean fingerroot extracts obtained using different extraction methods (i.e., organic solvent and hot water extractions) were investigated. More specifically, the antioxidant activities were evaluated using the hydroxyl and 2,2'-azino-bis (3-ethylbenzothiazoline-6-sulfonic acid) (ABTS ${ }^{\dagger}$ ) radical scavenging assays, while the anti-diabetic effects of the various solvent extracts of fingerroot were tested using the a-glucosidase inhibitory assay. Among the tested samples the 80\% methanolic (MeOH) extract showed the most potent activities, with $\mathrm{IC}_{50}$ values of $82.3 \pm 2.3$ and $75.0 \pm 2.4$ $\mu \mathrm{g} / \mathrm{mL}$, respectively for the hydroxyl and $\mathrm{ABTS}^{+}$radical scavenging activities. Also, the $80 \% \mathrm{MeOH}$ extract exhibited the greatest $\alpha$-glucosidase inhibitory effects, with an $\mathrm{IC}_{50}$ value of $151.6 \pm 3.6 \mu \mathrm{g} / \mathrm{mL}$. Finally, the total phenolic content of $80 \% \mathrm{MeOH}$ extract was found to be $106.0 \pm 1.7 \mathrm{mg}$ equivalent of gallic acid per $\mathrm{g}$ of extract. These results suggest that the $80 \% \mathrm{MeOH}$ extract of fingerroot can be considered as a new effective source of natural antioxidant and anti-diabetic materials.
\end{abstract}

Key words : fingerroot, a-glucosidase, hydroxyl, $\mathrm{ABTS}^{+}$, total phenolic contents

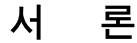

인체는 노화 방지를 위해 산화 촉진물질과 산화 억제 물질이 균형을 유지하며 방어체계를 이루고 있으나, 자외 선, 흡연, 매연, 방사선 및 스트레스 등의 여러 가지 요인들 에 의해 방어체계의 균형이 붕괴된다(Videla과 Fernandez, 1988). 이로 인해 과도하게 생성된 superoxide, nitric oxide, nitrogen dioxide, hydroxyl 및 peroxynitrite 등과 같은 활성산 소종(reactive oxygen species, ROS)은 산화적 스트레스를 유발하게 된다(Halliwell과 Aruoma, 1991). 이런 산화적 스 트레스는 세포의 구성성분인 지질, 단백질, 당 및 DNA 등에 비가역적으로 파괴를 촉진하여 노화와 관련된 각종 질병을 발생하는 원인이 된다(Jennings과 Barnett, 1988; Fang 등, 2002). 항산화 물질은 체내에서 불안정한 ROS나 자유라디칼을 중화시켜 노화방지 및 성인병 예방 등의 기 능을 하는 성분을 말하며, 대표적인 항산화제로 butylated

*Corresponding author. E-mail : skyey7@daegu.ac.kr, Phone : +82-53-850-6533, Fax : +82-53-850-6539

Received 12 November 2019; Revised 26 December 2019; Accepted 03 January 2020.

Copyright (c) The Korean Society of Food Preservation.

This is an Open Access article distributed under the terms of the Creative Commons Attribution Non-Commercial License (http://creativecommons.org/licenses/by-nc/4.0) which permits unrestricted non-commercial use, distribution, and reproduction in any medium, provided the original work is properly cited. 
hydroxy anisol(BHA) 및 butylated hydroxy toluene(BHT) 등 의 합성 항산화제가 있으나(Rubin과 Peyrot, 1999; Jennings 과 Akoh, 2009), 이들을 장기간 복용 시 암 유발 및 지질대 사 불균형 등의 부작용 등을 유발시킬 수 있어 사용제한을 권고하고 있다(Scawarz과 Mertz, 1959).

당뇨병은 고혈당 상태가 오랜 시간 지속됨에 따라 뇌졸 중, 심근경색, 협심증 및 족부 궤양 등 만성 합병증이 유발 하는 매우 위험한 대사성 질환으로 최근 급격한 경제 성장 및 서구화된 식습관으로 인해 당뇨병의 발병률이 크게 증가하고 있으며, 발병연령 또한 점차 낮아지고 있다(Patel 등, 2012). 최근 연구에서 당뇨병과 항산화 작용은 서로 밀접한 상관관계가 보고가 되었는데, 이는 췌장 베타세포 의 손상이 산화적 스트레스에 의해 발생되며, 이는 인슐린 분비 감소로 이어져 항산화 물질이 당뇨병 개선에 관련하 는 것으로 보고되었다(Scawarz과 Mertz. 1959). 소장에서 분비되는 $\alpha$-glucosidase는 단당류를 분해하는 소화효소로 이를 억제하면 탄수화물의 소화를 방해하여 당의 흡수가 지연되므로 혈관 내 급격한 혈당 상승을 막아준다 (Kihara 등, 1997; Tsujimoto 등, 2008). 현재까지 잘 알려진 $\alpha$ -glucosidase 저해제로는 acarbose 및 voglibose 등이 있으나, 이들을 장기 복용할 경우 복부 경련 및 팽만과 설사 등의 부작용이 보고되어 있어 보다 안전하고 효능이 우수한 천연 기능성 소재로부터 $\alpha$-glucosidase 저해제의 탐색이 필요한 실정이다(Chiasson 등, 1994; Coniff 등, 1995).

핑거루트(Boesenbergia rotunda)는 생강과에 속하는 식 물로 말레이시아, 태국 및 인도네시아 등의 동남아시아 일대가 원산지이며, 뿌리의 모양이 손가락을 닮아서 핑거 루트라고 부르고, 생강과 같은 풍미로 인해 조미료로도 많이 이용되어 왔다(Kiat 등, 2006). 인도네시아 전승의학 에서 치아 우식증, 감기 및 부종과 같은 염증성 질환 등을 치료하는데 사용되었다(Tuchinda 등, 2002; Yanti 등 2009; Voon 등, 2017; Kim 등, 2018). 이전 연구에서 동남아시아 산 핑거루트의 추출물로부터 terpenoid, flavonoid 및 chalcone류 등의 화합물이 구조 동정되었으며, 이들 화합 물은 항산화, 항염증, 항돌연변이 및 항바이러스성 활성 등의 다양한 생리활성이 보고되었다(Trakoontivakorn 등, 2001; Isa 등, 2012; Seniya 등, 2013). Wongsa 등(2012)은 태국산 핑거루트 열수 추출물의 $5,000 \mu \mathrm{g} / \mathrm{mL}$ 농도에서 $6.75 \%$ 의 저해활성으로 상대적으로 낮은 $\alpha$-glucosidase 저 해능을 보고하였다(Wongsa 등, 2012). 최근 국내에서 핑거 루트의 재배가 되고 있으며, 국산 핑거루트의 생리활성 기능에 대한 연구는 미미한 실정이다. 본 연구에서는 국산 핑거루트를 다양한 유기용매 및 열수를 활용하여 추출한 후 각 추출물에 대하여 총페놀성 화합물의 함량평가, 항산 화 활성과 관련된 hydroxyl 및 2,2'-azino-bis(3-ethylbenzo thiazoline-6-sulfonic acid)(ABTS ${ }^{+}$라디칼 소거활성 및 항
당뇨 활성과 관련된 $\alpha$-glucosidase 저해활성을 수행한 결과, 열수 추출보다 유기용매 추출물에서 매우 우수한 활성을 확인하였기에 이 결과를 보고하고자 한다.

\section{재료 및 방법}

\section{재료}

본 실험에 시료는 경기도 시흥시에서 2017년 9월에 수 확한 건조된 핑거루트(Boesenbergia pandurata)를 사용하 였다. 표본시료는 대구대학교의 식품공학과 천연물 화학 실험실에 보관하고 있으며, 기능성 평가에 사용된 시약은 gallic acid, ascorbic acid, (+)-catechin, 2,2'-azino-bis(3ethylbenzothiazoline-6-sulfonic acid)(ABTS ${ }^{+}$), acarbose, deoxyribose 및 Saccharomyces cerevisiae 유래의 $\alpha$-glucosidase 는 Sigma-Aldrich Chemical Co.(St. Louis, MO, USA) 구입하 여 사용하였고, 그 외에 사용된 용매 및 시약은 모두 일급 이상의 등급을 사용하였다.

\section{추출물 제조}

건조된 핑거루트 $5.0 \mathrm{~g}$ 을 분쇄기(HMF-3250S, Hanil Electric Co., Seoul, Korea)로 잘게 마쇄하여 사용하였으며, 유기용매 추출에는 $80 \%$ methyl alcohol $(\mathrm{MeOH}), 80 \%$ ethyl alcohol(EtOH), $80 \%$ acetone을 사용하였고, 각 유기용매 $200 \mathrm{~mL}$ 에 마쇄한 핑거루트를 하루 동안 침지 추출을 하였 으며, 3 회 반복 후 추출물을 얻었다. 열수 추출물은 마쇄한 핑거루트에 증류수 $200 \mathrm{~mL}$ 를 가하여 $100^{\circ} \mathrm{C}$ 에서 3 시간 동 안 추출하였다. 각 추출물은 filter paper로 여과한 후 저온 감압 농축한 뒤 건조하여 $80 \% \mathrm{MeOH}$ 추출물을 $430.2 \mathrm{mg}$, $80 \% \mathrm{EtOH}$ 추출물을 $520.7 \mathrm{mg}, 80 \%$ acetone을 추출물 621.4 $\mathrm{mg}$ 및 열수 추출물을 $693.4 \mathrm{mg}$ 을 각각 수득하였다(data not shown). 농축된 핑거루트 추출물을 대상으로 총페놀 함량 측정, hydroxyl 및 $\mathrm{ABTS}^{+}$라디칼 소거능과 $\alpha$-glucosidase 저 해능 평가를 수행하였다.

\section{총페놀성 화합물 함량 측정}

총페놀성 화합물의 함량은 Folin-Denis 방법(Gao 등, 2000)에 따라 측정하였으며, 각 용매별 추출물 $1.0 \mathrm{mg} / \mathrm{mL}$ 농도로 조제한 후, 시료 $50 \mu \mathrm{L}$ 와 Folin-Denis 시액 $50 \mu \mathrm{L}$, $0.7 \mathrm{M}$ 탄산나트륨 포화용액 $50 \mu \mathrm{L}$ 를 차례로 넣은 다음 이것을 잘 혼합하여 실온에서 60 분 방치한 후 ELISA reader (Infinite F200, Tecan Austria GmBH, Grödig, Austria)로 750 $\mathrm{nm}$ 에서 흡광도를 측정하였으며, 표준물질은 gallic acid를 이용하여 표준곡선을 작성하여 양을 환산하였다.

\section{Hydroxyl 라디칼 소거활성 측정}

건조된 핑거루트의 유기용매 추출물 및 열수추출물의 
hydroxyl 라디칼 소거활성은 deoxyribose 방법( $\mathrm{Li}, 2013)$ 을 변형하여 다음과 같이 측정하였다. $2.5 \mathrm{mM}$ deoxyribose, $1.5 \mathrm{mM} \mathrm{H}_{2} \mathrm{O}_{2}, 100 \mu \mathrm{M} \mathrm{FeCl}_{3}$ 및 $100 \mu \mathrm{M} \mathrm{EDTA}$ 를 $10 \mathrm{mM}$ phosphate buffer(pH 7.4)에 녹인 후 농도 별로 제조한 시료 에 첨가한다. 반응 시작 전 $100 \mu \mathrm{M}$ ascorbic acid를 첨가한 후 $37^{\circ} \mathrm{C}$ 에서 1 시간 동안 반응시킨다. 반응 후 $0.5 \%$ thiobarbituric acid와 $2.8 \%$ trichloroacetic acid를 첨가한 후 $80^{\circ} \mathrm{C}$ 의 온도에서 20 분 동안 가열한다. 이후 급속 냉각시킨 후 ELISA reader를 이용하여 $532 \mathrm{~nm}$ 에서 흡광도를 측정한 다. 이때 양성 대조군은 천연 항산화제인 (+)-catechin을 사용하였다.

Hydroxyl radical scavenging activity(\%)

$$
=\left(1-\frac{\mathrm{A}_{\text {sample }}-\mathrm{A}_{\text {blank }}}{\mathrm{A}_{\text {control }}}\right) \times 100
$$

Hydroxyl 라디칼 소거활성의 결과는 첨가군 $\left(\mathrm{A}_{\text {sample }}\right)$ 과 무첨가군 $\left(\mathrm{A}_{\text {blank }}\right)$ 의 흡광도 감소율 차이를 백분율로 환산하 여 나타내었다.

\section{$\mathrm{ABTS}^{+}$라디칼 소거활성 측정}

다양한 유기용매와 증류수를 사용하여 추출된 핑거루 트 각 추출물에 대하여 2,2'-azinobis-3-ethylbenzothiazoline6-sulfonic $\operatorname{acid}\left(\mathrm{ABTS}^{+}\right)$radical 소거활성을 $\mathrm{Re}$ 등(1999)의 방법을 변형하여 다음과 같이 측정하였다. $7 \mathrm{mM} \mathrm{ABTS}$ 와 $2.4 \mathrm{mM} \mathrm{K} \mathrm{O}_{8} \mathrm{~S}_{2}$ 동량을 혼합 후 암실에서 12시간 방치하여 라디칼의 생성을 유도한 후 $\mathrm{ABTS}^{+}$라디칼 용액을 희석하 여 $734 \mathrm{~nm}$ 에서 O.D 값이 0.7-0.8 정도가 되도록 희석한 후 사용하였다. 희석한 $\mathrm{ABTS}^{+}$라디칼 용액 $100 \mu \mathrm{L}$ 와 시료 $100 \mu \mathrm{L}$ 를 혼합하여 실온에서 7분간 반응시킨 후 ELISA reader로 $734 \mathrm{~nm}$ 에서 흡광도를 측정하였다. 이때 양성 대 조군으로는 (+)-catechin을 사용하였다.

$\mathrm{ABTS}^{+}$radical scavenging activity $(\%)$

$$
=\left(1-\frac{\mathrm{A}_{\text {sample }}-\mathrm{A}_{\text {blank }}}{\mathrm{A}_{\text {control }}}\right) \times 100
$$

$\mathrm{ABTS}^{+}$라디칼 소거활성의 결과는 첨가군 $\left(\mathrm{A}_{\text {sample }}\right)$ 과 무 첨가군 $\left(\mathrm{A}_{\text {blank }}\right)$ 의 흡광도 감소율 차이를 백분율로 환산하여 나타내었다.

\section{a-Glucosidase 저해활성 측정}

$\alpha$-Glucosidase 저해능은 Eom 등(2012)이 행한 방법을 변형하여 효소-기질반응을 이용한 분광학적 방법으로 측 정하였다. 즉, $1 \mathrm{U} / \mathrm{mL} \alpha$-glucosidase $90 \mu \mathrm{L}$ 에 시료 혹은
$0.1 \mathrm{M}$ sodium phosphate buffer(pH 6.8) $10 \mu \mathrm{L}$ 를 첨가하여 혼합한 후 $37^{\circ} \mathrm{C}$ 에서 15 분 동안 incubation 시켰다. 반응 후 기질인 $1 \mathrm{mM} p$-NPG(p-nitrophenyl- $\alpha$-D-glucopyranoside) $100 \mu \mathrm{L}$ 를 첨가한 후 5 분간 반응시키고, $405 \mathrm{~nm}$ 에서 ELISA reader를 이용하여 흡광도를 측정함으로써 기질로부터 유 리되어 나오는 $p$-nitrophenol을 측정하였다. 양성대조군으 로는 $\alpha$-glucosidase 저해제로 알려진 acarbose를 사용하였다.

$\alpha$-Glucosidase inhibitory effect(\%)

$$
=\left(1-\frac{\mathrm{A}_{\text {sample }}-\mathrm{A}_{\text {blank }}}{\mathrm{A}_{\text {control }}}\right) \times 100
$$

$\alpha$-Glucosidase 저해활성의 결과는 첨가군 $\left(\mathrm{A}_{\text {sample }}\right)$ 과 무첨 가군 $\left(\mathrm{A}_{\text {blank }}\right)$ 의 흡광도 감소율 차이를 백분율로 환산하여 나타내었다.

\section{통계처리}

실험결과는 SPSS package program(version 20.0, SPSS Inc., Chicago, IL, USA)을 이용하여 각 실험군 간의 유의성 을 검증한 후 Duncan's multiple range test에 의해 실험군 간의 차이를 $\mathrm{p}<0.05$ 유의수준에서 검증하였다.

\section{결과 및 고찰}

\section{총페놀성 화합물 함량 평가}

국산 핑거루트를 유기용매 및 열수를 이용한 각 추출물 을 대상으로 총페놀성 화합물의 함량을 측정하였다. 그 결과, 핑거루트 $80 \% \mathrm{EtOH}$ 추출물과 $80 \%$ acetone 추출물의 페놀 함량은 각각 $92.3 \pm 1.2 \mathrm{mg} \mathrm{GAE} / \mathrm{g}, 99.7 \pm 1.1 \mathrm{mg} \mathrm{GAE} / \mathrm{g}$ 을 함유하는 것으로 나타내었으며, $80 \% \mathrm{MeOH}$ 추출물에 는 총페놀성 화합물의 함량이 $106.0 \pm 1.7 \mathrm{mg} \mathrm{GAE} / \mathrm{g}$ 으로 $\mathrm{EtOH}$ 및 acetone 추출물에 비해 상대적으로 많은 페놀성 화합물을 함유하는 것으로 나타내었다. 하지만 열수 추출 물의 총페놀성 화합물의 함량은 $37.2 \pm 1.6 \mathrm{mg} \mathrm{GAE} / \mathrm{g}$ 으로

Table 1. Total phenolic contents of several extracts obtained from fingerroot

\begin{tabular}{cc}
\hline Samples & Total phenolic contents $(\mathrm{mg} \mathrm{GAE} / \mathrm{g})^{1)}$ \\
\hline $80 \%$ MeOH ext. & $106.0 \pm 1.7^{2) \mathrm{a}}$ \\
$80 \%$ EtOH ext. & $92.3 \pm 1.2^{\mathrm{b}}$ \\
$80 \%$ Acetone ext. & $99.7 \pm 1.1^{\mathrm{b}}$ \\
Hot water ext. & $37.2 \pm 1.6^{\mathrm{c}}$ \\
\hline${ }^{1)} \mathrm{GAE}:$ gallic acid equivalents. \\
${ }^{2)}$ Data represent the means \pm SD $(\mathrm{n}=3)$. Different letters $(\mathrm{a}-\mathrm{c})$ within \\
the same column indicate significant differences $(\mathrm{p}<0.05)$.
\end{tabular}


유기용매 추출물에 비해 상대적으로 낮은 페놀성 화합물 의 함량을 확인하였다(Table 1). 이상의 연구 결과, 핑거루 트의 페놀성 화합물을 추출은 열수 추출보다는 유기용매 를 이용한 추출이 조금 더 효과적인 추출방법임을 확인하 였다.

\section{Hydroxyl 라디칼 소거활성 평가}

다양한 유기용매 및 열수를 이용하여 국산 핑거루트를 추출한 후, 항산화 활성과 관련된 hydroxyl 라디칼 소거 활성 평가를 수행하였다. $80 \% \mathrm{MeOH}$ 를 이용하여 추출한 핑거루트 추출물의 $\mathrm{IC}_{50}$ 값이 $82.3 \pm 2.8 \mu \mathrm{g} / \mathrm{mL}$ 로 가장 우수 한 hydroxyl 라디칼 소거활성을 나타내었다. 다음으로 $80 \%$ acetone 추출물의 $\mathrm{IC}_{50}$ 값이 $123.4 \pm 1.3 \mu \mathrm{g} / \mathrm{mL}, 80 \% \mathrm{EtOH}$ 추출물의 $\mathrm{IC}_{50}$ 값이 $179.0 \pm 1.2 \mu \mathrm{g} / \mathrm{mL}$ 순으로 hydroxyl 라디 칼 소거활성을 나타내었다. 열수를 이용한 핑거루트 추출 물의 $\mathrm{IC}_{50}$ 값은 $400 \mu \mathrm{g} / \mathrm{mL}$ 이상으로 상대적으로 낮은 라디 칼 소거 활성을 나타내었다. 이상의 연구 결과로 핑거루트 는 유기용매 추출물에서 상대적으로 우수한 hydroxyl 라디 칼 소거활성을 나타내었으며, 특히 $80 \% \mathrm{MeOH}$ 추출물에 서 가장 강한 라디칼 소거능을 확인하였다(Table 2). 이전 연구에서 동남아시아에 자생하는 Ricinus communis 뿌리 의 $\mathrm{MeOH}$ 추출물에서 우수한 hydroxyl 라디칼 소거능이 보고가 되었고(Ilavarasan 등), Caesalpinia digyna 뿌리 추출 물로부터 강한 hydroxyl 라디칼 소거활성을 나타내는 페놀 유도체가 구조 동정되었다(Srinivasan 등, 2007).

\section{$\mathrm{ABTS}^{+}$라디칼 소거활성 평가}

본 연구에서는 국산 핑거루트를 각종 유기용매 및 열수 를 활용하여 추출한 뒤 항산화 활성과 관련된 $\mathrm{ABTS}^{+}$라디 칼 소거활성 평가를 수행하였다. 열수를 이용하여 추출한 핑거루트 열수 추출물의 $\mathrm{IC}_{50}$ 값은 $200 \mu \mathrm{g} / \mathrm{mL}$ 이상으로 상대적으로 낮은 $\mathrm{ABTS}^{+}$라디칼 소거 활성을 확인하였다.
하지만 유기용매를 이용하여 추출한 $80 \% \mathrm{EtOH}$ 및 acetone 추출물에서는 $\mathrm{ABTS}^{+}$라디칼 소거활성의 $\mathrm{IC}_{50}$ 값이 각 $88.9 \pm 3.3 \mu \mathrm{g} / \mathrm{mL}, 85.5 \pm 3.2 \mu \mathrm{g} / \mathrm{mL}$ 로 열수 추출물에 비해 상 대적으로 우수한 라디칼 소거활성을 확인하였다. 핑거루 트 $80 \% \mathrm{MeOH}$ 추출물의 $\mathrm{IC}_{50}$ 값이 $75.0 \pm 2.4 \mu \mathrm{g} / \mathrm{mL}$ 로 가장 우수한 $\mathrm{ABTS}^{+}$라디칼 소거 활성이 나타내었으며, hydroxyl 라디칼 소거활성 평가와 같은 양상을 나타내었다(Table 3). Hydroxyl 라디칼 소거능에서 가장 우수한 활성을 나타 낸 $80 \% \mathrm{MeOH}$ 추출물은 $\mathrm{ABTS}^{+}$라디칼 소거활성 평가에 서도 다른 추출방법에 비해 가장 강한 활성을 확인하였으 며, 총페놀 화합물이 상대적으로 가장 많이 함유되어 있는 $80 \% \mathrm{MeOH}$ 추출물에 라디칼을 효과적으로 소거하는 물질 의 존재가 시사되었다. 최근 연구에서 동남아시아에 흔히 자생하는 천연물인 Inula racemosa의 뿌리 추출물에서 우 수한 $\mathrm{ABTS}^{+}$라디칼 소거활성이 보고가 되었으며(Mohan 과 Gupta, 2017), 구지뽕나무(Cudrania tricuspidata) 뿌리 추출물로부터 강한 $\mathrm{ABTS}^{+}$라디칼 소거능을 나타내는 새 로운 prenyled flavanone이 구조 동정되었다(Lee 등, 2006). 이상의 연구 결과, 국산 핑거루트 $80 \% \mathrm{MeOH}$ 추출물에서 가장 강한 $\mathrm{ABST}^{+}$라디칼 소거활성을 확인하였으며, 이 활성을 추출물 상태의 활성으로 향후 각종 칼럼크로마토 그래피 및 기기분석을 활용하여 $80 \% \mathrm{MeOH}$ 추출물에 함 유되어 있는 우수한 라디칼 소거활성 물질의 구조 동정이 필요하다고 생각된다.

\section{a-Glucosidase 저해활성 평가}

국내에서 재배된 핑거루트를 유기용매 및 열수를 활용 한 추출물을 대상으로 항당뇨 활성과 관련된 $\alpha$-glucosidase 저해활성 평가를 수행하였다. 그 결과, 라디칼 소거능에서 낮은 활성을 나타낸 열수 추출물의 $\mathrm{IC}_{50}$ 값이 $500 \mu \mathrm{g} / \mathrm{mL}$ 이상으로 $\alpha$-glucosidase 저해능에서도 역시 상대적으로 낮 은 활성을 나타냈다. 핑거루트 $80 \% \mathrm{EtOH}$ 및 acetone 추출

Table 2. Comparison of hydroxyl radical scavenging activities of fingerroot extracts using different extraction conditions

\begin{tabular}{|c|c|c|c|c|c|c|}
\hline \multirow{2}{*}{ Samples } & \multicolumn{5}{|c|}{ Scavenging activity ${ }^{1)}(\%)$} & \multirow{2}{*}{$\begin{array}{c}\mathrm{IC}_{50} \\
(\mu \mathrm{g} / \mathrm{mL})\end{array}$} \\
\hline & $200 \mu \mathrm{g} / \mathrm{mL}$ & $100 \mu \mathrm{g} / \mathrm{mL}$ & $50 \mu \mathrm{g} / \mathrm{mL}$ & $25 \mu \mathrm{g} / \mathrm{mL}$ & $12.5 \mu \mathrm{g} / \mathrm{mL}$ & \\
\hline $80 \% \mathrm{MeOH}$ ext. & $73.2 \pm 0.8^{\mathrm{a}}$ & $59.0 \pm 0.7^{b}$ & $38.5 \pm 1.3^{\mathrm{c}}$ & $13.7 \pm 1.4^{\mathrm{e}}$ & $5.6 \pm 1.3^{\mathrm{f}}$ & $82.3 \pm 2.8^{\mathrm{c}}$ \\
\hline $80 \%$ EtOH ext. & $53.9 \pm 1.1^{b}$ & $31.2 \pm 1.3^{\mathrm{c}}$ & $7.8 \pm 2.4^{\mathrm{e}}$ & $5.1 \pm 1.1^{\mathrm{f}}$ & $1.1 \pm 0.8^{\mathrm{f}}$ & $179.0 \pm 1.2^{\mathrm{b}}$ \\
\hline $80 \%$ Acetone ext. & $63.9 \pm 2.1^{\mathrm{a}}$ & $48.0 \pm 0.9^{b}$ & $20.1 \pm 0.4^{\mathrm{d}}$ & $5.8 \pm 1.4^{\mathrm{f}}$ & $1.0 \pm 1.7^{\mathrm{f}}$ & $123.4 \pm 1.3^{\mathrm{b}}$ \\
\hline Hot water ext. & $22.8 \pm 1.7^{\mathrm{d}}$ & $11.7 \pm 1.8^{\mathrm{e}}$ & $5.5 \pm 0.9^{\mathrm{e}}$ & $1.4 \pm 1.9^{\mathrm{f}}$ & $0.7 \pm 0.1^{\mathrm{f}}$ & $>400^{\mathrm{a}}$ \\
\hline$(+)-$ Catechin $^{2)}$ & $88.1 \pm 2.1^{\mathrm{a}}$ & $72.3 \pm 1.1^{\mathrm{a}}$ & $62.3 \pm 1.9^{\mathrm{b}}$ & $40.5 \pm 1.5^{\mathrm{c}}$ & $31.1 \pm 1.3^{\mathrm{d}}$ & $33.1 \pm 1.1^{\mathrm{c}}$ \\
\hline
\end{tabular}

${ }^{1)}$ Scavenging activities are expressed as the means $\pm \mathrm{SD}$ of triplicate experiments. Different letters $(\mathrm{a}-\mathrm{f})$ within the same column indicate significant differences $(\mathrm{p}<0.05)$.

${ }^{2)}(+)$-Catechin was used as a positive control. 
Table 3. Comparison of $\mathrm{ABTS}^{+}$radical scavenging activities of fingerroot extracts using different extraction conditions

\begin{tabular}{|c|c|c|c|c|c|c|}
\hline \multirow{2}{*}{ Samples } & \multicolumn{5}{|c|}{ Scavenging activity $(\%)^{1)}$} & \multirow{2}{*}{$\begin{array}{c}\mathrm{IC}_{50} \\
(\mu \mathrm{g} / \mathrm{mL})\end{array}$} \\
\hline & $200 \mu \mathrm{g} / \mathrm{mL}$ & $100 \mu \mathrm{g} / \mathrm{mL}$ & $50 \mu \mathrm{g} / \mathrm{mL}$ & $25 \mu \mathrm{g} / \mathrm{mL}$ & $12.5 \mu \mathrm{g} / \mathrm{mL}$ & \\
\hline $80 \% \mathrm{MeOH}$ ext. & $76.5 \pm 1.8^{b}$ & $57.1 \pm 2.1^{\mathrm{c}}$ & $39.5 \pm 1.1^{\mathrm{d}}$ & $24.6 \pm 2.3^{\mathrm{e}}$ & $10.5 \pm 0.8^{\mathrm{f}}$ & $75.0 \pm 2.4^{\mathrm{b}}$ \\
\hline $80 \%$ EtOH ext. & $73.6 \pm 2.1^{\mathrm{b}}$ & $51.9 \pm 1.2^{\mathrm{c}}$ & $34.2 \pm 0.8^{\mathrm{d}}$ & $21.2 \pm 2.4^{\mathrm{e}}$ & $10.7 \pm 1.1^{\mathrm{f}}$ & $88.9 \pm 3.3^{b}$ \\
\hline $80 \%$ Acetone ext. & $74.9 \pm 0.9^{b}$ & $53.6 \pm 0.7^{\mathrm{c}}$ & $34.9 \pm 1.3^{\mathrm{d}}$ & $19.5 \pm 1.3^{\mathrm{e}}$ & $12.3 \pm 1.9^{\mathrm{e}}$ & $85.5 \pm 3.2^{\mathrm{b}}$ \\
\hline Hot water ext. & $43.3 \pm 1.4^{\mathrm{c}}$ & $28.9 \pm 1.7^{\mathrm{e}}$ & $12.3 \pm 1.1^{\mathrm{e}}$ & $4.8 \pm 3.1^{\mathrm{f}}$ & $2.7 \pm 2.5^{\mathrm{f}}$ & $>200^{\mathrm{a}}$ \\
\hline$(+)-$ Catechin $^{2)}$ & $99.9 \pm 0.7^{\mathrm{a}}$ & $98.7 \pm 0.2^{\mathrm{a}}$ & $93.2 \pm 1.7^{\mathrm{a}}$ & $84.2 \pm 1.3^{\mathrm{a}}$ & $77.8 \pm 1.6^{\mathrm{b}}$ & $6.4 \pm 1.8^{\mathrm{f}}$ \\
\hline
\end{tabular}

${ }^{1)}$ Scavenging activities are expressed as the means \pm SD of triplicate experiments. Different letters $(a-f)$ within the same column indicate significant differences $(\mathrm{p}<0.05)$.

${ }^{2)}(+)$-Catechin was used as a positive control.

Table 4. Comparison of a-glucosidase inhibitory effects of fingerroot extracts using different extraction conditions

\begin{tabular}{|c|c|c|c|c|c|c|}
\hline \multirow{2}{*}{ Samples } & \multicolumn{5}{|c|}{ Inhibition $(\%)^{1)}$} & \multirow{2}{*}{$\begin{array}{c}\mathrm{IC}_{50} \\
(\mu \mathrm{g} / \mathrm{mL})\end{array}$} \\
\hline & $500 \mu \mathrm{g} / \mathrm{mL}$ & $250 \mu \mathrm{g} / \mathrm{mL}$ & $125 \mu \mathrm{g} / \mathrm{mL}$ & $62.5 \mu \mathrm{g} / \mathrm{mL}$ & $31.3 \mu \mathrm{g} / \mathrm{mL}$ & \\
\hline $80 \% \mathrm{MeOH}$ ext. & $75.7 \pm 1.1^{\mathrm{b}}$ & $60.7 \pm 2.3^{\mathrm{b}}$ & $44.0 \pm 4.1^{\mathrm{c}}$ & $30.4 \pm 1.9^{c}$ & $25.9 \pm 2.9^{c}$ & $151.6 \pm 3.1^{\mathrm{b}}$ \\
\hline $80 \%$ EtOH ext. & $70.1 \pm 1.4^{\mathrm{b}}$ & $40.6 \pm 2.2^{\mathrm{c}}$ & $19.5 \pm 2.1^{\mathrm{d}}$ & $13.1 \pm 1.8^{\mathrm{d}}$ & $9.0 \pm 2.2^{\mathrm{e}}$ & $306.7 \pm 2.9^{\mathrm{a}}$ \\
\hline $80 \%$ Acetone ext. & $66.9 \pm 2.1^{\mathrm{b}}$ & $41.4 \pm 1.4^{\mathrm{c}}$ & $31.0 \pm 1.1^{\mathrm{c}}$ & $16.4 \pm 2.1^{\mathrm{d}}$ & $9.8 \pm 1.2^{\mathrm{e}}$ & $296.3 \pm 2.3^{\mathrm{a}}$ \\
\hline Hot water ext. & $24.6 \pm 1.0^{\mathrm{c}}$ & $19.7 \pm 2.1 \mathrm{~d}$ & $17.5 \pm 1.0^{\mathrm{d}}$ & $15.9 \pm 2.6^{\mathrm{d}}$ & $11.5 \pm 1.9^{d}$ & $>500^{\mathrm{a}}$ \\
\hline Acarbose $^{2)}$ & $65.9 \pm 1.1^{\mathrm{b}}$ & $49.5 \pm 1.8^{\mathrm{c}}$ & $25.4 \pm 1.9^{c}$ & $15.2 \pm 1.3^{\mathrm{d}}$ & $8.1 \pm 1.1^{\mathrm{e}}$ & $281.9 \pm 1.6^{\mathrm{a}}$ \\
\hline
\end{tabular}

${ }^{1)}$ Inhibitory effects are expressed as the means $\pm \mathrm{SD}$ of triplicate experiments. Different letters $(\mathrm{a}-\mathrm{e})$ within the same column indicate significant differences $(p<0.05)$.

${ }^{2}$ Acarbose was used as a positive control.

물의 $\mathrm{IC}_{50}$ 값이 $306.7 \pm 2.9 \mu \mathrm{g} / \mathrm{mL}, 281.9 \pm 2.3 \mu \mathrm{g} / \mathrm{mL}$ 로 양성 대조군인 acarbose $\left(\mathrm{IC}_{50}=281.9 \pm 1.6 \mu \mathrm{g} / \mathrm{mL}\right)$ 와 유사한 $\alpha$ glucosidase 저해활성을 나타내었다(Table 4). 핑거루트 $80 \% \mathrm{MeOH}$ 추출물의 $\mathrm{IC}_{50}$ 값은 $151.6 \pm 3.1 \mu \mathrm{g} / \mathrm{mL}$ 로 우수한 $\alpha$-glucosidase 저해활성을 나타내었으며, 라디칼 소거능에 서 가장 강한 활성을 나타낸 $80 \% \mathrm{MeOH}$ 추출물이 $\alpha$ glucosidase 저해능 평가에서도 역시 다른 추출방법에 비해 가장 강한 저해활성을 확인하였다. 이전 연구에서 더덕 (Codonopsis lanceolata) 추출물에서 우수한 $\alpha$-glucosidase 저해활성을 나타냄이 보고가 되었고(Jung 등, 2006), 상백 피(Morus alba L.)의 $\mathrm{MeOH}$ 추출물로부터 $\alpha$-glucosidase를 효과적으로 저해하는 chalcone 유도체가 구조 동정되었다 (Ha 등, 2018). 본 연구에서는 국내에서 재배된 핑거루트에 대한 $\alpha$-glucosidase 저해활성 평가는 처음으로 수행하였으 며, $80 \% \mathrm{MeOH}$ 추출물에서 가장 우수한 저해능을 확인하 였다. 향후 $\alpha$-glucosidase 저해활성을 나타낸 $80 \% \mathrm{MeOH}$ 추출물로부터 활성물질의 구조 동정이 필요하며, 세포 및 동물실험 등의 추가적인 효능 검증을 실시하여 새로운 $\alpha$-glucosidase 저해제로서의 가능성을 검증할 필요가 있다 고 생각된다.

\section{요 약}

핑거루트는 동남아시아가 주요 원산지이지만, 최근에 는 국내에서도 많이 재배되고 있다. 본 연구에서는 국내에 서 재배된 핑거루트를 $80 \% \mathrm{MeOH}, \mathrm{EtOH}$, acteone 및 열수 를 이용하여 추출한 후, 각 추출물에 대해 총페놀성 화합물 함량 평가와 항산화 활성과 관련된 hydoxyl 및 $\mathrm{ABTS}^{+}$라디 칼 소거능, 항당뇨 활성과 관련된 $\alpha$-glucosidase 저해능 평 가를 수행하였다. 총페놀성 화합물의 함량이 상대적으로 가장 많이 함유되어 있는 핑거루트 $80 \% \mathrm{MeOH}$ 추출물에 서 $\mathrm{IC}_{50}$ 값이 $82.3 \pm 2.8 \mu \mathrm{g} / \mathrm{mL}$ 로 다른 용매 추출방법에 비해 우수한 hydroxyl 라디칼 소거활성을 확인하였다. $\mathrm{ABTS}^{+}$ 라디칼 소거능 평가에서도 역시 $80 \% \mathrm{MeOH}$ 추출물에서 $\mathrm{IC}_{50}$ 값이 $75.0 \pm 2.4 \mu \mathrm{g} / \mathrm{mL}$ 의 가장 우수한 라디칼 소거활성 을 확인하였다. 또한, $\alpha$-glucosidase 저해능 평가에서도 $\mathrm{IC}_{50}$ 
값이 $151.6 \pm 3.1 \mu \mathrm{g} / \mathrm{mL}$ 의 $\alpha$-glucosidase 저해활성을 나타내 었으며, 다른 추출방법에 비해 우수한 저해활성임을 확인 하였다. 이상의 연구 결과, 국산 핑거루트를 효율적으로 추출하기 위해서는 열수보다 유기용매 추출이 효과적이 며, 특히 $80 \% \mathrm{MeOH}$ 추출물에서 가장 우수한 라디칼 소거 활성 및 $\alpha$-glucosidase 저해활성을 나타내었다. 또한, 이 활성은 복합적인 추출물 상태의 활성으로 향후 각종 칼럼 크로마토그래피 및 기기분석을 이용하여 활성을 나타내 는 화합물의 구조 동정이 필요하다고 생각된다. 또한, 현재 동남아산 핑거루트에 대한 연구가 주로 이루어져 있으며, 국산 핑거루트의 대한 세포 및 동물실험 등의 추가적인 활성 기작에 연구를 통하여 천연 기능성 소재 발굴을 위한 기초자료로 활용 가능할 것으로 사료된다.

\section{Conflict of interests}

The authors declare no potential conflict of interest.

\section{ORCID}

Gyeong Han Jeong

https://orcid.org/0000-0001-7115-4945

Tae Hoon Kim https://orcid.org/0000-0003-0428-2829

\section{References}

Chiasson JL, Josse RG, Hunt JA, Palmason C, Rodger NW, Ross SA, Ryan EA, Tan MH, Wolever TM. The efficacy of acarbose in the treatment of patients with noninsulin-dependent diabetes mellitus: A multicenter, controlled clinical trial. Ann Intern Med, 121, 928-935 (1994)

Coniff RF, Shapiro JA, Seaton TB, Bray GA. Multicenter, placebo-controlled trial comparing acarbose (BAY $g$ 5421) with placebo, tolbutamide, and tolbutamide-plusacarbose in non-insulin-dependent diabetes mellitus. Am J Med, 98, 443-451 (1995)

Eom SH, Lee SH, Yoon NY, Jung WK, Jeon YJ, Kim SK, Lee MS, Kim YM. $\alpha$-Glucosidase and $\alpha$-amylase inhibitory activities of phlorotannins from Eisenia bicyclis. J Sci Food Agric, 92, 2084-2090 (2012)

Fang YZ, Yang S, Wu G. Free radicals, antioxidants, and nutrition. Nutrition, 18, 872-879 (2002)

Gao X, Bjork L, Trajkovski V, Uggla M. Evaluation of antioxidant activities of rosehip ethanol extracts in different test systems. J Sci Food Agric, 80, 2021-2027
(2000)

Ha MT, Seong SH, Nguyen TD, Cho WK, Ah KJ, Ma JY, Woo MH, Choi JS, Min BS. Chalcone derivatives from the root bark of Morus alba L. act as inhibitors of PTP1B and $\alpha$-glucosidase. Phytochemistry, 155, 114-125 (2018)

Halliwell B, Aruoma OI. DNA damage by oxygen derived species its mechanism and measurement in mammalian systems. FEBS Lett, 281, 9-19 (1991)

Ilavarasan R, Mallika M, Venkataraman S. Anti-inflammatory and free radical scavenging activity of Ricinus communis root extract. J Ethnopharmacol, 103, 478-480 (2006)

Isa NM, Abdelwahab SI, Mohan S, Abdul AB, Sukari MA, Taha MME, Syam S, Narrima P, Cheah S. Ch, Ahmad $\mathrm{S}$, Mustafa MR. In vitro anti-inflammatory, cytotoxic and antioxidant activities of boesenbergin A, a chalcone isolated from Boesenbergia rotunda (L.) (fingerroot). Braz J Med Biol Res, 45, 524-530 (2012)

Jennings BH, Akoh CC. Effectiveness of natural versus synthetic antioxidants in a rice bran oil-based structured lipid. Food Chem, 114, 1456-1461 (2009)

Jennings PE, Barnett AH. New approaches to the pathogenesis and treatment of diabetic microangiopathy. Diabetic Med, 5, 111-117 (1988)

Jung SW, Han AJ, Hong HJ, Choung MG, Kim KS, Park SH. $\alpha$-Glucosidase inhibitors from the roots of Codonopsis lanceolata Trautv. Agric Chem Biotechnol, 49, 162-164 (2006)

Kiat TS, Pippen R, Yusof R, Ibrahim H, Khalid N, Rahman NA. Inhibitory activity of cyclohexenyl chalcone derivatives and flavonoids of fingerroot, Boesenbergia rotunda (L.), towards dengue-2 virus NS3 protease. Bioorg Med Chem Lett, 16, 3337-3340 (2006)

Kihara Y, Ogami Y, Tabaru A, Unoki H, Otsuki M. Safe and effective treatment of diabetes mellitus associated with chronic liver diseases with an alpha-glucosidase inhibitor, acarbose. J Gastroenterol, 32, 777-782 (1997)

Kim H, Kim C, Kim DU, Chung HC, Hwang JK. Inhibitory effects of Boesenbergia pandurata on age-related periodontal inflammation and alveolar bone loss in Fischer 344 rats. J Microbiol Biotechn, 28, 357-366 (2018)

Lee BW, Lee JH, Gal SW, Moon YH, Park KH. Selective ABTS radical-scavenging activity of prenylated flavonoids from Cudrania tricuspidata. Biosci Biotehnol Biochem, 70, 427-432 (2006)

Li X. Solvent effects and improvements in the deoxyribose degradation assay for hydroxyl radical-scavenging. Food 
Chem, 141, 2083-2088 (2013)

Mohan S, Gupta D. Phytochemical analysis and differential in vitro cytotoxicity assessment of root extracts of Inula racemosa. Biomed Pharmacother, 89, 781-795 (2017)

Patel D, Kumar R, Laloo D, Hemalatha S. Diabetes mellitus: An overview on its pharmacological aspects and reported medicinal plants having antidiabetic activity. Asian Pac J Trop Biomed, 2, 411-420 (2012)

Re R, Pellegrini N, Proteggente A, Pannala A, Yang M, Rice-Evans C. Antioxidant activity applying an improved ABTS radical cation decolorization assay. Free Radical Bio Med, 26, 1231-1237 (1999)

Rubin RR, Peyrot M. Quality of life and diabetes. Diabetes Metab Res Rev, 15, 205-218 (1999)

Scawarz K, Mertz W. Chromium (III) and the glucose tolerance factor. Arch Biochem, 85, 292-295 (1959)

Seniya C, Mishra H, Yadav A, Sagar N, Chaturvedi B, Uchadia K, Wadhwa, G. Antiviral potential of 4-hydroxypanduratin A, secondary metabolite of fingerroot, Boesenbergia pandurata (Schult.), towards Japanese Encephalitis virus NS2B/NS3 protease. Bioinformation, 9, 54-60 (2013)

Srinivasan RMJN, Chandrasekar MJN, Nanjan MJ, Suresh B. Antioxidant activity of Caesalpinia digyna root. J Ethnopharmacol, 113, 284-291 (2007)

Trakoontivakorn G, Nakahara K, Shinmoto H, Takenaka M, Onishi-Kameyama M, Ono H, Yoshida M, Nagata T, Tsushida T. Structural analysis of a novel antimutagenic compound, 4-hydroxypanduratin $\mathrm{A}$, and the antimutagenic activity of flavonoids in a Thai spice, fingerroot
(Boesenbergia pandurata Schult.) against mutagenic heterocyclic amines. J Agric Food Chem, 49, 3046-3050 (2001)

Tsujimoto T, Shioyama E, Moriya K, Kawaratani H, Shirai Y, Toyohara M, Mitoro A, Yamao J, Fuji H, Fukui H. Pneumatosis cystoides intestinalis following alphaglucosidase inhibitor treatment: A case report and review of the literature. World J Gastroenterol, 14, 6087-6092 (2008)

Tuchinda P, Reutrakul V, Claeson P, Pongprayoon U, Sematong T, Santisuk T, Taylor WC. Anti-inflammatory cyclohexenyl chalcone derivatives in Boesenbergia pandurata. Phytochemistry, 59, 169-173 (2002)

Videla LA. Fernandez V. Biochemical aspects of cellular oxidative stress. Arch Biol Med Exp, 21, 85-92 (1988)

Voon FL, Sulaiman MR, Akhtar MN, Idris MF, Akira A, Perimal EK, Israf DA, Ming-Taff L. Cardamonin (2',4'dihydroxy-6'-methoxychalcone) isolated from Boesenbergia rotunda (L.) Mansf. inhibits CFA-induced rheumatoid arthritis in rats. Eur J Pharmacol, 794, 127-134 (2017)

Wongsa P, Chaiwarit J, Zamaludien A. In vitro screening of phenolic compounds, potential inhibition against $\alpha$ -amylase and $\alpha$-glucosidase of culinary herbs in Thailand. Food Chem, 131, 964-971 (2012)

Yanti, Anqqakusuma, Gwon SH, Hwang JK. Kaempferia pandurata Roxb. inhibits Porphyromonas gingivalis supernatant-induced matrix metalloproteinase-9 expression via signal transduction in human oral epidermoid cells. J Ethnopharmacol, 123, 315-324 (2009) 